\title{
THE INFLUENCE OF RELIGIOSITY AND SPIRITUALITY TOWARDS STUDENTS' PSYCHOLOGICAL WELL-BEING DURING COVID-19 PANDEMIC
}

\section{Ecep Supriatna}

IKIP Siliwangi, Indonesia

Jl. Terusan Jend. Sudirman, Cimahi, Jawa Barat, Indonesia, 40521

Email: ecep83supriatna@gmail.com

\section{Muhammad Rezza Septian}

IKIP Siliwangi, Indonesia

Jl. Terusan Jend. Sudirman, Cimahi, Jawa Barat, Indonesia, 40521

Email: rezza.septian25@gmail.com

Received: 01, 2021. Accepted: 06, 2021. Published: 06, 2021

\begin{abstract}
This article aims to examine the influence of religiosity and spirituality on the students' psychological well-being during the Covid-19 pandemic. The method used is a relational survey method. The participants of this research were 627 students who studied in universities located in Bandung and Cimahi. The universities included State Islamic University of Sunan Gunung Djati Bandung, the Indonesian Education University, Jenderal Ahmad Yani University, and the Siliwangi Institute of Teacher Training and Education. The data were collected using a questionnaire instrument consisting of a questionnaire of religiosity, spirituality, and psychological well-being. The results showed that both religiosity and spirituality had an effect on psychological well-being. It is shown that religiosity had a higher effect than spirituality on students' psychological well-being during the Covid-19 pandemic.
\end{abstract}

Keywords: Religiosity, Students' Psychological Well-Being, Spirituality

\section{ABSTRAK}

Artikel ini bertujuan untuk mengkaji pengaruh religiusitas dan spiritualitas terbadap kesejabteraan psikologis mahasiswa selama masa pandemi Covid-19. Metode yang digunakan adalah metode survei relasional. Partisipan penelitian ini adalah 627 mahasiswa yang menempuh pendidikan di perguruan tinggi yang berada di Bandung dan Cimabi. Universitas tersebut antara lain Universitas Islam Negeri Sunan Gunung Djati Bandung, Universitas Pendidikan Indonesia, Universitas Jenderal Ahmad Yani, dan IKIP Siliwangi. Pengumpulan data menggunakan instrumen angket yang terdiri dari angket religiusitas, spiritualitas, dan kesejabteraan psikologis. Hasil penelitian menunjukkan bahwa religiusitas dan spiritualitas berpengaruh terhadap kesejabteraan psikologis. Religiusitas memiliki efek yang lebih tinggi daripada spiritualitas terhadap kesejabteraan psikologis mahasiswa selama pandemi Covid-19.

Kata Kunci: Kesejabteraan Psikologis Mahasiswa, Religiusitas, Spiritualitas 


\section{INTRODUCTION}

Psychological well-being is an important topic in psychological research. This construct is usually conceptualized as something positive related to affective combinations such as happiness and functions with optimal effectiveness in individual and social life (Deci \& Ryan, 2008). According to Huppert (2009), "psychological well-being is about a life that goes well, which is a combination of having good feelings and functioning effectively. Furthermore, psychological well-being refers to the degree to which people feel that they have meaningful control over their lives and their activities.

In the context of education, psychological well-being is an interesting topic to investigate since it is related to the challenges faced by students during learning. One of the challenges is related to stress in learning which is an inevitable part in students' academic life (Gallagher, 2009). Although several sources of stress are necessary for personal growth to occur, the amount of stress can overwhelm a student and affect their ability to cope with problems (Kumaraswamy, 2013). DuBois et al. (2015) examine the relationship between positive psychological construction and health. The result is that positive psychological construction (e.g., hope, optimism) has an effect on health. In most studies, the term psychological health defined as the development of one's state of mind into an optimal state in the sphere of maintaining physical, mental, and emotional adaptation with others (Sun et al., 2020).

COVID-19 pandemic has been the global health problem in the current situation. Various communities from all walks of life around the world are struggling to cope with the pandemic. The World Health Organization (WHO) declared COVID-19 a global public health emergency of international concern on 30 January 2020 and a pandemic on 11 March 2020 (Cucinotta \& Vanelli, 2020). During the pandemic, community activities were no longer the same as they used to be before the pandemic. Various countries in the world impose regulations for working from home, learning from home, social distancing, physical distancing, etc. In addition, these adjustments can ultimately trigger symptoms of mental health and psychological disorders (Arnout et. al., 2020; Liebrenz et. al., 2020).

COVID-19 poses a serious impact on students, instructors and education around the world (Mailizar et. al., 2020). The pandemic has brought closure for schools, colleges and universities around the world to curb the spread of the virus. Students can follow social and physical distancing measures (Toquero, 2020). However, a smooth movement from conventional educational environments to distance learning or online learning cannot happen overnight. Changes occur in relation to the obstacles and challenges faced today (Crawford et. al., 2020). However, because no one knows when the pandemic will completely disappear, eventually educational institutions around the world have decided to use online learning (Kaur, 2020).

Objection and resistance to online learning because of its challenges have been raised by many parties. Challenges faced by higher education students in developing countries include lack of access to internet facilities, lack of proper interaction and contact between students and lecturers and ineffective use of technology (Ahmad, 2020). Other studies reported additional challenges faced by students such as lack of campus socialization, group study problems and lecturer response times (Adnan, 2020) and lacks of physical activity that has an impact on students' mental health (Jones et al., 2013). Researchers found that people who engage in physical activity generally have better mental health (Mytton, Panter, \& Ogilvie, 2016; Tamminen et al., 2020) (Panter \& Ogilvie, 2016; Tamminena, 2020)

In an online education, one of the less discussed areas is the need for motivation to participate in online learning (Adnan, 2020). In traditional classrooms, students usually participate actively in academic activities with lecturers and classmates. As many as $71.4 \%$ of 
students reported that conventional classroom learning was more motivating than distance learning. To ensure an effective and productive online program, students should know how to deal with fast-paced online classes and possess good computer and technology skills to learn online with their lectures. Equipped with this digital literacy, students can manage study time effectively and handle some difficulties. Their problem occurs when they do group assignments without face-to-face interaction with group members. They face many problems as conveyed by $42.9 \%$ of respondents. To deal with those problems in online learning, Psychology has many things to offer. It features a better understanding of people's reactions and behaviors related to pandemics, and reduces their impact on health and psychological well-being (Bavel et al., 2020).

Increasing level of psychological well-being can be done through various ways. Some of them have something to do with personality variables, demographic factors such as gender, education, and income (Diener \& Seligman, 2002; Eryllmaz, 2010). Some of the variables that influence psychological well-being are religiosity and spirituality. Religiosity and spirituality have been evaluated as internal factors, which have an impact on the subjective well-being of individuals (Holder, Coleman, \& Wallace, 2010). The proposition of religiosity and spirituality contribute to individuals' perceived psychological and physical well-being. The issue has been repeatedly demonstrated in empirical research (Krause, 2010; Levin \& Chatters, 1998; Mueller, Plevak, \& Rummans, 2001).

Religiosity is a short term used in various domains of religious activity, dedication, and belief (religious doctrine). It is described in terms of religious beliefs and practices regarding a religious membership or an authority and power of God (Pargament, 1997; Shafranske \& Malony, 1990). The expression of individual religiosity in religious life is related to belief systems, values, applicable laws and religious practices, spirituality, and high moral quality (Kavros, 2014; Kaye \& Raghvaran, 2000). Furthermore, religiosity refers to the level of individual attachment to their religion. This is indicated by individuals who have lived and internalized the teachings of their religion so that they are influential in all their actions and perspectives on life (Risnawita, 2014).

Spirituality has been defined as an awareness of the power that transcends the material aspects of life outside of the individual and an awareness of wholeness and connection with the universe (Myers \& Williard (2003). It has the connotation of interconnection and selftranscendence as a form opposite to self-centeredness. It can also be interpreted as the transcendence of the highest achievement in individual development, motivation that encourages individuals to seek meaning and purpose in life, human characteristics that distinguish individuals from other creatures, and human dimensions which are indicators of the level of individual mental health (Ingersoll, \& Bauer, 2004).

Religiosity and spirituality relates each other. Religiosity becomes a pattern of institutionalized values, beliefs, symbols, behavior and experiences, which are directed at spirituality, are known together in society, and are passed down through tradition (Canda \& Furman, 2010). While spirituality is defined as a process of searching for meaning, purpose, morality, well-being in relation to oneself, others, and ultimate reality. Thus, individuals express their spirituality in a religious setting (in relation to ultimate reality) or non-religious (in relation to oneself, others, and even the universe).

There is a difference between religiosity and spirituality. While religiosity is considered to be formal and institutional because it reflects a commitment to beliefs and practices according to certain religious traditions, spirituality is associated with personal experience and is functional, reflecting individual efforts to obtain the purpose and meaning of life (Zinnbauer \& Pergament, 2005). In its function, spirituality has similarities with religiosity in the sense of helping individuals understand various things or problems in their life. However, 
the framework used to understand these issues may have differences. In religiosity, there are theological bases, guidelines, and guidelines from religion, so this is used as a framework or reference for understanding it. While spirituality does not contain these guidelines, it becomes a personal search for each individual (Lesmawati, 2016).

The issue on religiosity, spirituality, and their effect on the psychological well-being of students are under studied. This study tries to fill the gap. The researchers want to focus on seeing the extent to which religiosity and spirituality are related or have an effect on the psychological well-being of students during the COVID-19 pandemic situation with university students as the subject.

\section{METHOD}

This research is a quantitative study using a relational survey method to determine whether there is a relationship between two or more variables (Kline, 2011; Tabachnick \& Fidell, 2013). Participants in this study were students studying at campuses in Bandung and Cimahi, namely the State Islamic University of Sunan Gunung Djati Bandung, Universitas Pendidikan Indonesia, Jenderal Ahmad Yani University, and IKIP (Institut Keguruan dan Ilmu Pendidikan/Institute of Education and Teacher Training) Siliwangi. They were selected randomly from various batches. The number of participants in this study was 627 students. This research consisted of two independent variables and one dependent variable. The independent variables in this study are Religiosity and Spirituality. While the dependent variable is Psychological Well-Being. Data were collected using questionnaires. A religiosity questionnaire consisting of 12 statement items adapted from Dali et al., (2019) as shown in Table 1. A Spirituality questionnaire consisting of 16 statement items was adapted from Underwood (2002) as shown in Table 2. A psychological well-being questionnaire consisting of 18 statement items adapted from Ryff \& Keyes (1995) as shown in Table 3.

Tabel 1. Religiosity Scale Development (Dali et al., 2019)

\begin{tabular}{ll}
\hline No & Statement Items \\
\hline 1. & Muhammad SAW is the last prophet of Allah SWT \\
\hline 2. & I believe there is only one God \\
\hline 3. & I believe the teachings of the Quran are appropriate for life \\
\hline 4. & All the good deeds of mankind will be judged and rewarded \\
\hline 5. & I believe the traditions of the Prophet are appropriate all the time \\
\hline 6. & Religious beliefs affect what I consume \\
\hline 7. & I make sure that the clothes I wear cover my aurat (part of body that are not allowed to be seen) \\
\hline 8. & I always do dhikr \\
\hline 9. & I follow the Sunnah in my daily life \\
\hline 10. & My whole approach to life is based on religion \\
\hline 11. & I regularly pray five times a day \\
\hline 12. & I am fasting in the month of Ramadan \\
\hline
\end{tabular}

Tabel 2. The Daily Spiritual Experience Scale (Underwood, 2002).

\begin{tabular}{ll}
\hline No & Statement Items \\
\hline 1. & I feel the presence of God \\
\hline 2. & I experience connection with all life \\
\hline 3. & When I connect with God, I feel happy, where everyday problems are helped \\
\hline 4. & I find strength in religion or spirituality \\
\hline 5. & I find comfort in religion or spirituality \\
\hline 6. & I feel a deep inner peace or harmony \\
\hline 7. & I ask God's help in the midst of daily activities \\
\hline 8. & I feel guided by God in the midst of daily activities \\
\hline
\end{tabular}




\begin{tabular}{ll}
\hline No & Statement Items \\
\hline 9. & I felt God's love for me, firsthand \\
\hline 10. & I feel God's love for me, through other people \\
\hline 11. & Spiritually touched I was touched by the beauty of God's creation \\
\hline 12. & I feel grateful \\
\hline 13. & I give selflessly to others \\
\hline 14. & I accept other people even when they do things that I think are wrong \\
\hline 15. & I want to be closer to God \\
\hline 16. & I feel close to God \\
\hline
\end{tabular}

Tabel 3. Psychological Well-Being scales (Ryff \& Keyes, 1995).

\begin{tabular}{ll}
\hline No & Statement Items \\
\hline 1. & I like most of my personality \\
\hline 2. & When I see the story of life that has been experienced, I am happy with what happened \\
\hline 3. & Some people live aimlessly, but I am not one of them \\
\hline 4. & The demands of everyday life often stress me out \\
\hline 5. & In many ways, I feel disappointed with the achievements of life so far \\
\hline 6. & Keeping in touch with other people is very difficult and frustrating for me \\
\hline 7. & I live one day at a time and don't think much about the future \\
\hline 8. & In general, I feel responsible for the situation in which I live. \\
\hline 9. & I am good at managing the responsibilities of daily life \\
\hline 10. & I have done everything there is to do in life \\
\hline 11. & For me, life is a continuous process of learning, change and growth \\
\hline 12. & I think it's important to have new, challenging experiences \\
\hline 13. & Others see me as an individual who is willing to give and share time with others \\
\hline 14. & I stopped trying to make major improvements or changes in my life \\
\hline 15. & I tend to be influenced by the opinions or opinions of others \\
\hline 16. & I have yet to experience a warm and trusting relationship with another person \\
\hline 17. & I have faith in my own opinions, even if they differ from those of others \\
\hline 18. & Judge yourself based on what's important to me, not based on what other people think \\
\hline
\end{tabular}

To test the hypothesis, multiple regression statistical method was used. The data analysis in this study used multiple linear regression analysis, and previously classical assumption test was administered.

1. Classical Assumption Test

The classical assumption test used was the normality test, multicollinearity test and heteroscedasticity test.

a. Normality Test

The data normality test was performed using one sample Kolmogorov Smirnov. The results of the normality test obtained a significance result (asymp. Sig. (2-tailed) of 0.200 , because the results is sig $0.200>0.05$, it can be stated that the data in this study were normally distributed.

b. Multicollinearity Test

Based on the results of the multicollinearity test, the tolerance for each variable was $0.677(0.677>0.10)$ and a VIF value of $1.478(1.478<10)$, so it can be stated that there is no multicollinearity problem in this study.

c. Heteroscedasticity Test

To find out heteroscedasticity in multiple linear regression, we can look at the scatterplot graph in Figure 1. It can be seen that the dots form a pattern that spreads above and below the number 0 on the $\mathrm{Y}$ axis, this supports that there is no heteroscedasticity problem in this research model. 


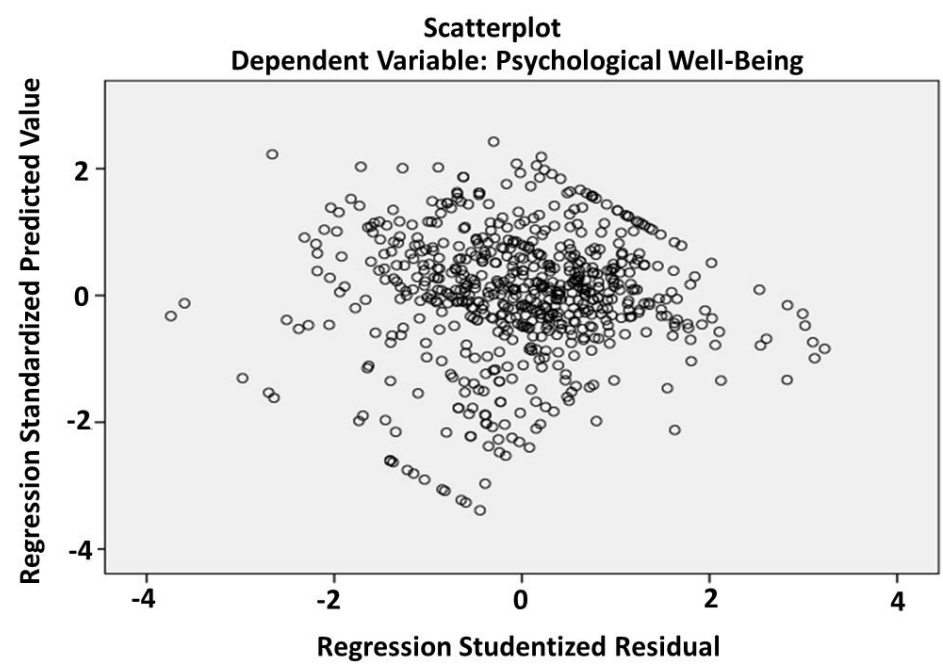

Figure 1. Heteroscedasticity Test Scatterplot Graph.

2. Multiple Linear Regression Analysis

The results of data processing on multiple linear regression analysis on the effect of religiosity, spirituality on psychological well-being, can be seen in the following table 1:

Table 1. Multiple Linear Regression Analysis

\begin{tabular}{|c|c|c|c|c|c|}
\hline \multicolumn{6}{|c|}{ Coefficients $^{a}$} \\
\hline \multirow[b]{2}{*}{ Model } & Unstanc & ed Coefficients & Standardized Coefficients & & \\
\hline & B & Std. Error & Beta & $\mathrm{T}$ & Sig. \\
\hline 1 (Constant) & 4.427 & 1.366 & & 3.241 & 0.001 \\
\hline Religiosity & 0.854 & 0.048 & 0.546 & 17.651 & 0.000 \\
\hline Spirituality & 0.339 & 0.033 & 0.316 & 10.220 & 0.000 \\
\hline
\end{tabular}

Based on the Table 1, a multiple linear regression equation was obtained, as follows:

$$
\mathrm{Y}=4.427+0.854 \mathrm{X} 1+0.339 \mathrm{X} 2+_{-} \mathrm{e}
$$

The multiple linear regression equation above can be interpreted as follows:

a. The constant is 4.427 , meaning that if religiosity and spirituality are worth 0 (zero) and there is no change, then psychological well-being will still be worth 4.427.

b. The regression coefficient for religiosity is 0.854 which is positive, which means that if religiosity increases one-by-one, while spirituality is constant, then psychological wellbeing will increase by 0.854 .

c. The regression coefficient for spirituality is 0.339 which is positive, which means that if spirituality increases one unit, while religiosity is constant, then psychological well-being will increase by 0.339 .

\section{RESULTS AND DISCUSSION}

\section{Analysis of the coefficient of determination}

The coefficient of determination is used to measure the ability of the independent variable to the dependent variable.

Table 2. Simultaneous Determination Coefficient

\begin{tabular}{llccc}
\hline \multicolumn{5}{c}{ Model Summary } \\
\hline Model & $\mathrm{R}$ & $\mathrm{R}$ Square & $\begin{array}{c}\text { Adjusted R } \\
\text { Square }\end{array}$ & $\begin{array}{c}\text { Std. Error of } \\
\text { the Estimate }\end{array}$ \\
\hline 1 & $0.772^{\mathrm{a}}$ & 0.595 & 0.594 & 5.903 \\
\hline Predictors: (Constant), Spirituality, Religiosity \\
\hline
\end{tabular}


Based on the Table 2, the calculation of the coefficient of determination is $0.7722 \mathrm{x}$ $100 \%=59.5 \%$, this shows that $59.5 \%$ of the influence of the independent variables which are religiosity and spirituality contributes to the dependent variable of psychological well-being, while the remaining $40.5 \%$ is the contribution of influence from other variables outside of this research. In order to gain the influence of each independent variable on the dependent variable partially, the calculation was done using the formula $\mathrm{Kd}=$ Zero Order $\mathrm{x} \beta \mathrm{x} 100 \%$. Based on the results of data processing, the partial determination results were obtained, as follows:

Table 3. Partial Determination Coefficient

\begin{tabular}{|c|c|c|c|c|c|c|c|c|}
\hline \multirow[b]{3}{*}{ Model } & \multicolumn{5}{|c|}{ Coefficients $^{a}$} & & & \\
\hline & \multicolumn{2}{|c|}{$\begin{array}{c}\text { Unstandardized } \\
\text { Coefficients }\end{array}$} & \multirow{2}{*}{$\begin{array}{c}\begin{array}{c}\text { Standardized } \\
\text { Coefficients }\end{array} \\
\text { Beta }\end{array}$} & \multirow[b]{2}{*}{$\mathrm{T}$} & \multirow[b]{2}{*}{ Sig. } & \multicolumn{3}{|c|}{ Correlations } \\
\hline & B & Std. Error & & & & $\begin{array}{l}\text { Zero- } \\
\text { order }\end{array}$ & Partial & Part \\
\hline 1 (Constant) & 4.427 & 1.366 & & 3.241 & 0.001 & & & \\
\hline Religiosity & 0.854 & 0.048 & 0.546 & 17.651 & 0.000 & 0.726 & 0.577 & 0.449 \\
\hline Spirituality & 0.339 & 0.033 & 0.316 & 10.220 & 0.000 & 0.627 & 0.379 & 0.260 \\
\hline
\end{tabular}

Dependent Variable: Psychological Well-being

Based on the Table 3, the partial determination coefficient was calculated, as follows:

Religiosity: $0.546 \times 0.726=0.396396$ or $39.64 \%$

Spirituality: $0.316 \times 0.627=0.198132$ or $19.81 \%$

Based on calculations, the results show that the greatest contribution to the psychological well-being variable comes from the religiosity variable of $39.64 \%$, while spirituality contributes $19.81 \%$.

3. Hypothesis Testing

a. F-Test (Simultaneous Hypothesis)

The F statistical test is also called the simultaneous significant test. This $\mathrm{F}$ test shows whether there is a simultaneous influence of religiosity and spirituality on psychological wellbeing.

Decision Making Criteria:

Ho is accepted and $\mathrm{Ha}$ is rejected, if $\mathrm{f}_{\text {count }}<\mathrm{f}_{\text {table }}$ and $\mathrm{p}_{\text {value }}>0.05$.

Ho is rejected and $\mathrm{Ha}$ is accepted, if $\mathrm{f}_{\text {count }}>\mathrm{f}_{\text {table }}$ and $\mathrm{p}_{\text {value }}<0.05$.

The table is obtained from the probability of $5 \%$, df1 $=2$ and df $2=627-2=625$, then the result is 3.010 .

Based on the results of data processing, the results of simultaneous hypothesis testing with the F-test were obtained, as follows:

Table 4. F-Test (Simultaneous Hypothesis)

\begin{tabular}{|c|c|c|c|c|c|c|}
\hline \multicolumn{7}{|c|}{ ANOVA $^{a}$} \\
\hline Model & & Sum of Squares & Df & Mean Square & $\mathrm{F}$ & Sig. \\
\hline \multirow[t]{3}{*}{1} & Regression & 31996.973 & 2 & 15998.486 & 459.065 & $.000^{\mathrm{b}}$ \\
\hline & Residual & 21746.495 & 624 & 34.850 & & \\
\hline & Total & 53743.467 & 626 & & & \\
\hline
\end{tabular}

a. Dependent Variable: Psychological Well-being

b. Predictors: (Constant), Spirituality, Religiosity

Based on the Table 4 , the result of $f_{\text {count }}$ was 459,062 with a significance ( $p_{\text {value }}$ ) of 0.000 , because the results of $f_{\text {count }}>f_{\text {table }}(459.062>3.010)$ and a significance $\left(p_{\text {value }}\right)$ of $0.000<0.05$, 
then $\mathrm{Ho}$ is rejected and $\mathrm{Ha}$ is accepted, so it can be stated that religiosity and spirituality simultaneously have a significant effect on psychological well-being.

b. T-test (Partial Hypothesis)

This statistical test shows how far the influence of the independent variable partially affect the dependent variable, in this case knowing whether there is a partial influence of religiosity and spirituality on psychological well-being.

Decision Making Criteria:

Ho is accepted and $\mathrm{Ha}$ is rejected, if $\mathrm{t}_{\text {count }}<\mathrm{t}_{\text {table }}$ and $\mathrm{p}_{\text {value }}>0.05$.

Ho is rejected and $\mathrm{Ha}$ is accepted, if $\mathrm{t}_{\text {count }}>\mathrm{t}_{\text {table }}$ and $\mathrm{p}_{\text {value }}<0.05$.

$\mathrm{t}_{\text {table }}$ was obtained from the probability of $5 \%$, and $\mathrm{df}=627-2=625$, then the result is 1.964.

Based on the results of data processing, the results of simultaneous hypothesis testing with the T-test were obtained, as follows:

Table 5. T-test (Partial Hypothesis)

\begin{tabular}{|c|c|c|c|c|c|}
\hline \multicolumn{6}{|c|}{ Coefficients $^{a}$} \\
\hline \multirow[b]{2}{*}{ Model } & \multicolumn{2}{|c|}{ Unstandardized Coefficients } & \multirow{2}{*}{$\frac{\text { Standardized Coefficients }}{\text { Beta }}$} & \multirow[b]{2}{*}{$\mathrm{T}$} & \multirow[b]{2}{*}{ Sig. } \\
\hline & B & Std. Error & & & \\
\hline 1 (Constant) & 4.427 & 1.366 & & 3.241 & 0.001 \\
\hline Religiosity & 0.854 & 0.048 & 0.546 & 17.651 & 0.000 \\
\hline Spirituality & 0.339 & 0.033 & 0.316 & 10.220 & 0.000 \\
\hline
\end{tabular}

Based on the Table 5, from the results of partial hypothesis testing (T-test), the results of each variable are as follows:

1) The Effect of Religiosity on Psychological Well-Being

The result of $t_{\text {count }}$ on the religiosity variable was obtained at 17.651 with a significance $\left(p_{\text {value }}\right)$ of 0.000 , because the results of $t_{\text {count }}>t_{\text {table }}(17.651>1.964)$ and the significance $\left(p_{\text {value }}\right)$ of $0.000<0.05$, then Ho was rejected and Ha was accepted, so it could be stated that religiosity partially had a significant impact on psychological well-being.

2) The Influence of Spirituality on Psychological Well-Being

The results of $t_{\text {count }}$ on the spirituality variable were obtained at 10.220 with a significance $\left(p_{\text {value }}\right)$ of 0.000 , because the results of $t_{\text {count }}>t_{\text {table }}(10.220>1.964)$ and a significance $\left(\mathrm{p}_{\text {value }}\right)$ of $0.000<0.05$, then Ho was rejected and $\mathrm{Ha}$ was accepted, so it could be stated that spirituality partially had a significant impact on psychological well-being.

Based on the results of this study, religiosity and spirituality affect students' psychological well-being during the COVID-19 pandemic. The COVID-19 pandemic is the global collective trauma event (Duane, et al., 2020). Collective trauma is an event that disrupts everyday life for the whole community, becoming traumatic to those directly affected (Silver \& Updegraff, 2013) and has negative psychological consequences (Goldmann, E., \& Galea, 2014). Symptoms of anxiety and stress may occur in response to the COVID-19 pandemic. Some studies have shown a relationship between religiosity and health (Galen, 2018; Paloutzian \& Park, 2013).

Religion in this case Religiosity plays an important role in human life, and even has a major influence on psychological well-being (Otman et. al., 2020) such as on behavior, personality (Mueller, Plevak, \& Rummans, 2001), emotional peace (Kasan, 2002), selfconfidence and happiness in life (Hamka, 1997). The practice and internalization of religion carried out in religiosity possess a role in the formation of human personality (Othman, et. al., 2020) because each religion has its own belief values. Spirituality brings a varied and unique form of happiness and satisfaction. Spirituality can build a meaningful and comprehensive taxonomy of spiritual life, thus having something more substantial (Mike, 2016). Baldacchino (2015) found that spirituality in students and the academic community environment has a 
conducive impact on learning. Furthermore, a broader view of spirituality management can raise awareness about the various issues at hand (Ross et al., 2014; Ross et al., 2016). Schnitker et al., (2017) argues that the meaning of spirituality and religiosity is an understanding of the manifestations of patience that become the tendency of individuals to calm down in the face of frustration, difficulty, or suffering (Schnitker, 2012). Spirituality becomes a resource that can contribute to personal resilience to understanding, confronting, and overcoming adversity (Gulbrandsen \& Walsh, 2014). Religiosity encourages the formation of virtue in individuals through personal and communal spiritual practices such as prayer that fosters gratitude (Lambert et al, 2009).

Several studies support the role of religiosity in psychological well-being are education (Dolan, \& Peasgood, 2008; Smith, \& Faris, 2005). They can help understand individuals to interact and maintain more meaningful relationships with others. Compton (2005) argues that religiosity is a protective factor that prevents various individual and social problems. Benson (1995) found that participation in religious activities was significantly associated with higher well-being, and lower levels of social problems. (Bartlett et. al., 2003) also found that religiosity has a positive effect in reducing depression. Religiosity causes higher life satisfaction and satisfaction compared to those of non-religious individuals (Raudatussalamah \& Susanti, 2017). The impact of happiness and life satisfaction is significant at all age levels (Poloma, 1991). Firdaos (2017) explained that religiosity is a quality of religious understanding based on religious values is believed to consciously affect one's happiness. Stavrova, Fetchenhauer, \& Schlösser (2013) reveals religious people live happier lives than those who are not diverse.

McCullough, Emmons, \& Tsang, (2002) conclude that the relationship between religiosity and psychological well-being can be explained by how individuals use their religion to cope with life stressors. Pargament et. al. (1998) explain that there are five factors that cause religiosity to affect psychological well-being.

In the development of their lives, humans seek tranquility by getting closer to God by implementing religious values (Hill \& Smith, 2002). In Islam, Allah SWT says that the effort to get closer and get the happiness of the world and the hereafter is to do righteous deeds. As stated in the holy Quran Surat An-Nahl verse 97. Peace of mind is obtained when someone feels sufficient and grateful for the blessing of Allah SWT (HR. Bukhari and Muslim). The Quran explains how important it is to perform zikerullâh to reassure the hearts of His believing servants. Thus individuals who are mentally healthy are individuals who can synergize knowledge and bring up piety which is reflected in their attitude (Sholeh \& Musbikin, 2005). Rafi'udin \& Zainudin (2004) stated that a part from the psychological impact, ablution also has a physiological effect, because by washing the body parts five times a day, all the more so, it will help rest organs and relieve physical and psychological tension.

The values of religiosity that are applied in personal life make it possible to be adopted as part of an organizational system that will help individuals understand the complexity of roles and motivate them to interpret life so that they can achieve life satisfaction or happiness (well-being) (Dewi, Madjid, \& Fauzan, 2020). Individuals have an important role in improving psychological well-being. Positive social religious identity is associated with greater psychological well-being (Haslam et.al., 2009). Those with a religious social identity can access a positive social identity linked to their group membership which offers a strong sense of belonging. The strength of religious identity partly play a role as mediator between religious participation and subjective well-being (Greenfield \& Marks, 2007).

Motivation to be religious is classified as intrinsic or extrinsic, and religious motivation has been linked to psychological well-being. Intrinsic religious orientation is associated with less frequent perceptions of stress, reduced anxiety, and depression (Masters \& Bergin, 1992). Integration and social support are long-established predictors of good mental and physical 
health (Cohen, 2004). Participation in religious activities instills the individual in a social network of other like-minded people, an environment that can foster highly supportive relationships that enhance well-being (George, Ellison, \& Larson, 2002; Krause, Ellison \& Wulff, 1998).

Positive emotions have been linked to good mental health (Haslam et. al., 2009) and physical health (Diener \& Chan, 2011). Religious activities, including prayer and attending services, can produce positive emotions including admiration, forgiveness, gratitude, hope and joy (Levin, 2010). Many studies have established mental and physical health benefits due to the belief that a person can determine important outcomes in life (Gadalla, 2009), as well as health risks from attributing control to external sources, such as luck or destiny (Gale, Batty, \& Deary, 2008). The effect of the belief that God has supreme control (ie, "divine control") on health is more complex, belief in divine control can increase a person's sense of personal control (Pargament, 1997) perhaps because it is perceived as God's gift of free will. At the very least, belief in divine control can offer comfort and hope in a world that seems out of control.

\section{CONCLUSION}

The variables of religiosity and spirituality have proven to have an influence on students' psychological well-being during the Covid-19 pandemic. To compare the two variables, religiosity has a greater influence on students' psychological well-being than spirituality. The result of $t_{c o u n t}$ on the religiosity variable was obtained at 17.651. Taken into account this statistical result, it could be said that religiosity had a significant impact on psychological wellbeing. The results of $t_{\text {count }}$ on the spirituality variable were obtained at 10.220 . It could be stated that spirituality partially had a significant impact on psychological well-being. During the COVID-19 pandemic, religiosity and spirituality affect students' psychological well-being.

\section{BIBLIOGRAPHY}

Adnan, M. \& K. A. (2020). Online Learning Amid the COVID-19 Pandemic: Students' Perspectives. Journal of Pedagogical Sociology and Psychology, 2(1), 45-51. https://doi.org/10.33902/JPSP. 2020261309

Ahmad, I. (2020). Fata and the Internet. https://www.thenews.com.pk/print/639470-fata-andthe-internet

Amir, Y. \& Lesmawati, D. R. (2016). Religiusitas dan Spiritualitas: Konsep yang Sama atau Berbeda? 2(2), 67-73. https://doi.org/10.22236/JIPP-21

Arnout, B. A., Al-Dabbagh, Z. S., Al Eid, N. A., Al Eid, M. A., Al- Musaibeh, S. S., Al-Miqtiq, M. N., Alamri, A. S., \& Al-Zeyad, G. M. (2020). The Effects of Corona Virus (COVID19) Outbreak on the individuals' Mental Health and on the Decision Makers: A comparative Epidemiological Study. Health Sciences, 9(3), 26-47. Retrieved from https://pesquisa.bvsalud.org/global-literature-on-novel-coronavirus-2019ncov/resource/pt/covidwho-1085730

Baldacchino, D. (2015). Spiritual Care Education of Health Care Professionals. Religions, 6, 594-613. https://doi.org/10.3390/rel6020594

Bartlett, S. J., Piedmont, R., Bilderback, A., Matsumoto, A. K., \& Barthon, J. M. (2003). Spirituality, Well-Being, and Quality of Life in People with Rheumatoid Arthritis. Arthritis \& Rheumatism, 49, 778-783. https://doi.org/10.1002/art.11456

Benson, D. \&. (1995). Religion and the Well-Being of Adolescents. Journal of Social Issues, 51(2). Canda, E.R., \& Furman, L. D. (2010). Spiritual Diversity in Social Work Practice: The Heart of Helping. Oxford University Press. 
Cohen, S. (2004). Social Relationships and Health. The American Psychologist, 59(8), 676-684. https://doi.org/10.1037/0003-066X.59.8.676

Compton, W. C. (2005). An Introduction to Positive Psychology. Thomson Wadsworth Inc.

Crawford, J., Butler-Henderson, K., Rudolph, J., \& Glowatz, M. (2020). COVID-19: 20 Countries' Higher Education Intra-Period Digital Pedagogy Responses. Journal of Applied Teaching and Learning (JALT), 3(1). https:/ /doi.org/10.37074/jalt.2020.3.1.7

Cucinotta, D., \& Vanelli, M. (2020). WHO Declares COVID-19 a Pandemic. Acta Bio-Medica: Atenei Parmensis, 91(1), 157-16. https://doi.org/10.23750/abm.v91i1.9397.

Dali., Yousafzai., H. (2019). Religiosity Development Scale. Journal of Islamic Marketing.

Deci, E. L., \& Ryan, R. M. (2008). Hedonia, Eudaimonia, and Well-Being: An Introduction. Journal of Happiness Studies, 9, 1-11. https://doi.org/10.1007/s10902-006-9018-1

Dewi, S. S., Madjid, A., \& Fauzan, A. (2020). The Role of Religiosity in Work-Life Balance. Budapest International Research and Critics Institute (BIRCI-Journal): Humanities and Social Sciences, 3(3), 2363-2374. https://doi.org/10.33258/birci.v3i3.1192

Diener, E., \& Chan, M. Y. (2011). Happy People Live Longer: Subjective Well-Being Contributes to Health and Longevity. Applied Psychology: Health and Well-Being, 3(1), 1-43. https://doi.org/10.1111/j.1758-0854.2010.01045.x

Diener, E., \& Seligman, M. E. P. (2002). Very Happy People. Psychological Science, 13, 81-84. https://doi.org/10.1111/1467-9280.00415

Dolan, P., Peasgood, T., \& W. (2008). Do We Really Know What Makes Us Happy A Review of the economic Literature on the Factors Associated with Subjective Well-Being. Journal of Economic Psychology, 29(1), 94-122. https://doi.org/10.1016/j.joep.2007.09.001

Duane, A. M., Stokes, K. L., DeAngelis, C. L., \& Bocknek, E. L. (2020). Collective Trauma and Community Support: Lessons from Detroit. Psychological Trauma: Theory, Research, Practice and Policy, 12((5)), 452-454. https://doi.org/10.1037/tra0000791

DuBois, C. M., Lopez, O. V., Beale, E. E., Healy, B. C., Boehm, J. K., \&, \& Huffman, J. C. (2015). Relationships between Positive Psychological Constructs and Health Outcomes in Patients with Cardiovascular Disease: A Systematic Review. International Journal of Cardiology, 195, 265 - 280. https://doi.org/10.1016/j.ijcard.2015.05.121

Eryllmaz, A. (2010). Developing a Scale about Subjective Well-Being Increases Strategies for Adolescents. Journal of Turkish Psychological Counseling, 33, 81-88. Retrieved from https://dergipark.org.tr/en/pub/tpdrd/issue/21453/229692

Firdaos, R. (2017). Emotional Intelligence, Religiosity, and Social Attitude of Students. Jurnal Pendidikan Indonesia, 3(1). https://doi.org/10.15575/jpi.v3i1.828

Gadalla, T. M. (2009). Determinants, Correlates and Mediators of Psychological Distress: A Longitudinal Study. Social Science \& Medicine, 68(12), 2199-2205. https://doi.org/10.1016/j.socscimed.2009.03.040

Gale, C. R., Batty, G. D., \& Deary, I. J. (2008). Locus of Control at Age 10 Years and Health Outcomes and Behaviors at Age 30 Years: The 1980 British Cohort Study. Psychosomatic Medicine, 70(4), 397-403. https://doi.org/ 10.1097/PSY.0b013e31816a719e

Hamka. (1997). Tasauf Moden (Edisi Baru). Pustaka Nasional PTE LTD.

Galen, L. W. (2018). Focusing on the Nonreligious Reveals Secular Mechanisms Underlying Well-Being and Prosociality. Psychology of Religion and Spirituality, 10(3), 296-306. https://doi.org/10.1037/rel0000202

Gallagher, R. P. (2009). National Survey of Counelling Centre Directors 2008. Project Report. The International Association of Counselling Services (LACS). www.dscholarship.pitt.edu /28169/ 
George, L. K., Ellison, C. G., \& Larson, D. B. (2002). Explaining the Relationships between Religious Involvement and Health. Psychological Inquiry, 13(3), 190-200. https://doi.org/10.1207/S15327965PLI1303_04

Goldmann, E., \& Galea, S. (2014). Mental Health Consequences of Disasters. Annual Review of Public Health, 35(1), 169-183. https://doi.org/10.1146/annurev-publhealth-032013182435

Greenfield, E. A., \& Marks, N. F. (2007). Religious Social Identity as an Explanatory Factor for Associations between More frequent Formal Religious Participation and Psychological Well-Being. The International Journal for the Psychology of Religion, 17(3), 245259. https://doi.org/10.1080/10508610701402309

Gulbrandsen, Carolyne \& Walsh, A, C. (2014). Spirituality as Strength. The International Journal of Religion and Spirituality in Society, 3(4), 97-112. https://doi.org/10.18848/21548633/CGP/v03i04/51076

Hamka. (1997). Tasauf Moden (Edisi Baru). (Singapura). Pustaka Nasional PTE LTD.

Haslam, S. A., Jetten, J., Postmes, T., \& Haslam, C. (2009). Social Identity, Health and WellBeing: An Emerging Agenda for Applied Psychology. Applied Psychology: An International Review, 58(1), 1-23. https://doi.org/10.1111/j.1464-0597.2008.00379.x

Hill, P. C. and Smith, G. S. (2002). Coming to Terms Spirituality and Religion in The Workplace. In C. L. In Giacalone, R. A. \& Jurkiewicz (Ed.), Handbook of Workplace Spirituality and Organizational Performance. M. E. Sharpe.

Holder, M. D., Coleman, B., \& Wallace, J. M. (2010). Spirituality, Religiousness, and Happiness in Children Aged 8-12 Years. Journal of Happiness Studies, 11(2), 131-150. https://doi.org/10.1007/s10902-008-9126-1

Huppert, F. A. (2009). Psychological well-being: Evidence Regarding Its Causes and Consequences. Applied Psychology: Health and Well-Being, 1, 137-164. https://doi.org/10.1111/j.1758-0854.2009.01008.x

Ingersoll, A. L \& Bauer, R. E. (2004). Professional School Counseling. Special Issue: Spirituality And School Counseling. Professional School Counseling, 7(5), 301-308.

Jones, A., Perkins, C., Stansfield, J., Mason, J., O’Keefe, M., McHale, P., et al. (2013). North West Mental wellbeing survey 2012/13. Public Health England, Liverpool John Moores University.

Kasan, K. (2002). Kesihatan Jasmani dan Rohani sebagai Asas Kejayaan Menurut Islam. Pusat Pengajian Umum.

Kaur, G. (2020). Digital Life: Boon or Bane in Teaching Sector on COVID-19. CLIO an Annual Interdisciplinary Journal of History, 6(6), 416-427.

Kavros, P. (2014). Religiosity. in David A. Leeming, Kathryn Madden, Stanton Marlan (Eds.) Encyclopedia of Psychology and Religion. Springer.

Kaye, J., \& Raghvaran, S. K. (2000). Spiritualy in Disability and Ilness: The Psychology of Religion and Coping. Guildford.

Kline, R. B. (2011). Principles and Practice of Structural Equation Modeling. Guilford Press.

Krause, N., Ellison, C. G., \& Wulff, K. M. (1998). Church-based Support, Negative Interaction and Psychological Well-Being: Findings from a National Sample of Presbyterians. Journal for the Scientific Study of Religion, 37(4), 725-741. https://doi.org/10.2307/1388153

Krause, N. (2010). Religious Involvement, Humility, and Self-Rated Health. Social Indicators Research, 98, 23-39. https://doi.org/10.1007/s11205-009-9514-x

Kumaraswamy, N. (2013). Academic stress, Anxiety and Depression among College Studentsa Brief Review. International Review of Social Sciences and Humanities, 1(5), 135- 143. 
Levin, J. (2010). Religion and Mental Health: Theory and Research. International Journal of Applied Psychoanalytic Studies, 7(2), 102-115.

Lambert, N. M., Fincham, F. D., Braithwaite, S. R., Graham, S. M., \& Beach, S. R. H. (2009). Can Prayer Increase Gratitude? Psychology of Religion and Spirituality, 1(3), 139-149. https://doi.org/10.1037/a0016731

Levin, J. S., \& Chatters, L. M. (1998). Religion, Health, and Psychological Well-Being in Older Adults: Findings from Three National Surveys. Journal of Aging and Health, 10(4), 504-531. https://doi.org/10.1177/089826439801000406.

Levin, J. (2010). Religion and Mental Health: Theory and Research. International Journal of Applied Psychoanalytic Studies, 7(2), 102-115. https://doi.org/10.1002/aps.240

Liebrenz, M., Bhugra, D., Buadze, A., \& Schleifer, R. (2020). Caring for Persons in Detention Suffering with Mental Illness during The Covid-19 Outbreak. Forensic Science International: Mind and Law, 1, 1-2. https://doi.org/10.1016/j.fsiml.2020.100013

Mailizar, Almanthari, A., Maulina, S., \& Bruce, S. (2020). Secondary School Mathematics Teachers' Views on E-Learning Implementation Barriers during The Covid-19 Pandemic: The Case of Indonesia. Eurasia Journal of Mathematics, Science and Technology Education, 16(7), 1860. https://doi.org/10.29333/ejmste/8240

Masters, K. S., \& Bergin, A. E. (1992). Religious Orientation and Mental Health in J. F. Schumaker (Ed.), Religion and Mental Health. Oxford University Press.

McCullough, M. E., Emmons, R. A., \& Tsang, J.-A. (2002). The Grateful Disposition: A Conceptual and Empirical Topography. Journal of Personality and Social Psychology, 82(1), 112-127. https://doi.org/10.1037/0022-3514.82.1.112

Mike, K. (2016). The Epistemology of Spiritual Happiness. Journal for the Study of Spirituality, 6(2), 142-154. https://doi.org/DOI: 10.1080/20440243.2016.1235169

Mueller, P., Plevak, D. J., \& Rummans, T. A. (2001). Religious Involvement, Spirituality, and Medicine: Implications for Clinical Practice. Mayo Clinic Proceedings, 76(12), 1225-1235. https://doi.org/10.4065/76.12.1225.

Myers, J. E., \& Williard, K. (2003). Integrating Spirituality Into Counselor Preparation: A Developmental, Wellness Approach. Counseling and Values, 47(2), 142-155. https://doi.org/10.1002/j.2161-007x.2003.tb00231.x

Mytton, O. T., Panter, J., \& Ogilvie, D. (2016). Longitudinal Associations of Active Commuting with Wellbeing and Sickness Absence. Preventive Medicine: An International Journal Devoted to Practice and Theory, 84, 19-26. https://doi.org/10.1016/ j.ypmed.2015.12.010

Othman, W. N. W., Zainudin, Z. N., Amat, N. A. C., \& Mokhtar, M. Y. O. (2020). Religious Appreciation and Psychological Well-Being Among Malaysian Army. Journal of Business and Social Sciences 1(11), 229-243. https://doi.org/10.6007/IJARBSS/v10-i11/8079

Paloutzian, R. F., \& Park, C. L. (2013). Handbook of the Psychology of Religion and Spirituality. The Guilford Press.

Pargament, K. I., Smith, B. W., Koenig, H. G., \& Perez, L. (1998). Patterns of Positive and Negative Religious Coping with Major Life Stressors. Journal for the Scientific Study of Religion, 37(4), 710-724. https://doi.org/10.2307/1388152

Pargament, K. I. (1997). The Psychology of Religion and Coping. Guilford Press.

Poloma, M. M. \& Pendleton, B. F. (1991). Exploring Neglected Dimensions of Religion in Quality of Life Research. The Edwin Mellen Press.

Rafi'udin \& Zainudin, A. (2004). Terapi Kesehatan Jiwa Mmelalui Ibadab Sbalat. Restu Ilahi.

Raudatussalamah \& Susanti, R. (2017). The Role of Religiousity: Keikutsertaan dalam Pembinaan Keislaman Mahasiswa dan Implikasinya terhadap Kesejahteraan Psikologis Mahasiswa Tahun Pertama. Jurnal Psikologi Islam, 4(2), 181-190. 
Gufron, M. N \& Risnawati, R. (2014). Teori-teori Psikologi. Ar-Ruzz media.

Ross, L., Leeuwen, R. V., Baldacchino, D., Giske, T., McSherry, W., Narayanasamy, A., Downes, C., Jarvis, P., \& Akkerman, A. S. (2014). "Student Nurses' Perceptions of Spirituality and Competence in Delivering Spiritual Care: A European Pilot Study". Nurse Education Today, 34, 697-702. https://doi.org/10.1016/j.nedt.2013.09.014.

Ross, L., Giske, T., Leeuwen, R.V., Baldacchino, D., McSherry, W., Narayanasamy, A., Jarvis, P., Downes, C., \& Akkerman, A. S. (2016). Factors Contributing to Student Nurses'Midwives' Perceived Competency in Spiritual Care. Nurse Education Today, 36, 445-451. https://doi.org/10.1016/j.nedt.2015.10.005

Ryff, C. D., \& Keyes, C. L. M. (1995). The Structure of Psychological Well-Being Revisited. Journal of Personality and Social Psychology, 69(4), 719-727.

Schnitker, S. A., Houltberg, B., Dyrness, W., \& Redmond, N. (2017). The Virtue of Patience, Spirituality, and Suffering: Integrating Lessons from Positive Psychology, Psychology of Religion, and Christian Theology. Psychology of Religion and Spirituality, 9, 264-275. https://doi.org/10.1037/rel0000099

Schnitker, S. A. (2012). An Examination of Patience and Well-Being. The Journal of Positive Psychology, 7, 263-280. https://doi.org/10.1080/17439760.2012.697185

Shafranske, E. P., \& Malony, H. N. (1990). Clinical Psychologists, Religious and Spiritual Orientations and Their Practice of Psychotherapy. Psychotherapy, 27, 72-78. http:/ /dx.doi.org/10.1037/0033-3204.27.1.72

Sholeh, M \& Musbikin, I. (2005). Agama sebagai Terapi. Pustaka Pelajar.

Silver, R. C., \& Updegraff, J. A. (2013). Searching for and Finding Meaning Following Personal and Collective Traumas. The Psychology of Meaning, 237-255. https://doi.org/10.1037/14040-012

Smith, C., \& Faris, R. (2005). Socioeconomic Inequality in the American Religious System: An Update and Assessment. Journal for the Scientific Study of Religion, 44(1), 95-104.

Stavrova, O., Fetchenhauer, D., \& Schlösser, T. (2013). Why are Religious People Happy? The Effect of The Social Norm of Religiosity Across Countries. Social Science Research, 42((1)), 90- 105. https://doi.org/10.1016/j.ssresearch.2012.07.002

Sun, J., Sun, R., Jiang, Y., Chen, X., Li, Z., Ma, Z., Wei, J., He, C., \&, \& Zhang, L. (2020). The Relationship between Psychological Health One, and Social Support: Evidence from Physicians in China. PLoS, 15(1). https://doi.org/10.1371/journal.pone.0228152

Tabachnick, B. G. \& Fidell, L. S. (2013). Using Multivariate Statistics. Pearson.

Tamminen, N., Reinikainen, J., Appelqvist-Schmidlechner, K., Borodulin, K., Mäki-Opas, T., \& Solin, P. (2020). Associations of Physical Activity with Positive Mental Health: A Population-Based Study. Mental Health and Physical Activity. https://doi.org/10.1016/j.mhpa.2020.100319

Underwood, L. G. \& Teresi, J. A. (2002). The Daily Spiritual Experience Scale: Development, Theoretical Description, Reliability, Exploratory Factor Analysis, and Preliminary Construct Validity Using Health-Related Data. Ann Bebav Med, 24(1). https://doi.org/10.1207/S15324796ABM2401_04.

Toquero, C. M. (2020). Challenges and opportunities for higher education amid the COVID19 pandemic: The Philippine Context. Pedagogical Research, 5(4).

Zinnbauer, B., \& Pergament, K. I. (2005). Religiousness and Spirituality. In R. F. Paloutzian, \& C.L. Park (Eds), Handbook of the psychology. 